\title{
Mengemas Kelas Bahasa Inggris (EFL) melalui Joyful Learning Based Social Constructivism Pedagogy
}

\author{
Husnul Huda, Nuna Mustikawati Dewi, Lulut Widyaningrum \\ MTs NU 02 Al Ma'arif Boja, \\ Universitas Islam Negeri Walisongo Semarang \\ Email : khuzhadi@gmail.com
}

\begin{abstract}
Joyful Learning as a learning process in which there is a strong cohesion between educators and learners, without any feelings of forced or depressed to make learners dare to do, dare to try, dare to ask, express opinions, and defend opinions so as not to fear wrong, ridiculed, underestimated and depressed. The purpose of this article is to illustrate the empowerment of madrasah English teachers with Joyful Learnig-Based Social Constructivism Pedagogy in the EFL Class. In implementing the concept of joyful based social constructivism pedagogy, the program is designed in four stages including socialization and training; class-class modeling; teacher engagement in classroom practice; and mentoring teachers to practice independently in the classes. In general, the English teachers in the two accompanying madrassas have been able to implement the concept of joyful based social constructivism pedagogy through a variety of methods and techniques that vary especially in brainstorming and ice breaking.
\end{abstract}

Abstrak: Joyful Learning sebagai suatu proses pembelajaran yang didalamnya terdapat sebuah kohesi yang kuat antara pendidik dan peserta didik, tanpa ada perasaan terpaksa atau tertekan sehingga membuat peserta didik berani berbuat, berani mencoba, berani bertanya, mengemukakan pendapat, dan mempertahankan pendapat sehingga tidak takut salah, ditertawakan, diremehkan dan tertekan. Tujuan dari artikel ini adalah menggambarkan pemberdayaan guru bahasa Inggris madrasah dengan Joyful Learnig-Based Social Constructivism Pedagogy dalam Kelas EFL. Dalam mengimplemetasikan konsep joyful based social constructivism pedagogy ini, program didesain dalam empat tahap yang meliputi sosialisasi dan pelatihan; pemberian modelling dikelas-kelas; pelibatan guru dalam praktik di kelas-kelas; dan pendampingan guru untuk praktik secara mandiri di kelas-kelas. Secara umum, para guru bahasa Inggris di dua madrasah yang didampingi sudah mampu mengimplemetasikan konsep joyful based social constructivism pedagogy melalui berbagai macam metode dan teknik yang bervariasi khususnya dalam brainstorming dan ice breaking.

Kata kunci: joyful learning; social constructivism pedagogy; Kelas EFL. 


\section{PENDAHULUAN}

Pendidikan merupakan kebutuhan primer pada saat ini. Mengingat pentingnya pendidikan, sebagian besar masyarakat mulai menjadikanya prioritas utama dalam menata masa depan yang lebih baik. Tak heran jika negara senantiasa berusaha memajukan bidang pendidikan, di samping bidang yang lain dalam rangka mempersiapkan sumber daya manusia yang kompetitif dan berkualitas serta berusaha mengejar kemajuan negara lain.

Penting bagi seorang pendidik untuk menciptakan paradigma baru untuk mengha-silkan praktik terbaik dalam proses pembelajaran (Carolin Rekar Munro, 2005). Hal ini karena pendidik harus memainkan peran utama dalam mencapai harapan dantujuan mulia dari pendidikan. Ronald Brandt (1993) menyatakan bahwa hampir semua usaha dalam pendidikan, seperti pembaharuan kurikulum, penerapan metode pembelajaran hingga proses evaluasi akhirnya akan sangat tergantung kepada pendidik. Tanpa pendidik yang mampu menguasai bahan ajar dan strategi pembelajaran, maka segala upaya peningkatan mutu pendidikan tidak akan mencapai hasil yang optimal. Tentu saja tuntutan ini tidak hanya pada mata pelajaran tertentu saja melainkan pada semua mata pelajaran termasuk Bahasa Inggris. Salah satu yang diyakini keterampilan penting yang harus dikuasai pendidik yang dapat membantu keberhasilan suatu proses belajar mengajar adalah kempuan menciptakan Joyful Learning atau pembelajaran menyenangkan.

Pendekatan Joyful Learning membuat peserta didik berani berbuat, berani mencoba, berani bertanya, mengemukakan pendapat, dan mempertahankan pendapat sehingga tidak takut salah, ditertawakan, diremehkan dan tertekan. Semua itu penting dan harus disadari oleh semua pendidkan karena dalam belajar pendidik harus menyadari bahwa otak manusia bukanlah mesin yang dapat disuruh berpikir tanpa henti, sehingga perlu relaksasi. Tentu saja joyful learning perlu dikombinasikan dengan pendekatan-pendekatan belajar lain salah satunya adalah sosial konstrukstivisme pedagogik.

Secara umum, pendekatan konstruktivisme sosial menekankan pada konteks sosial dari pembelajaran dan bahwa pengetahuan itu dibangun dan dikontruksi secara bersama (mutual). Keterlibatan dengan orang lain membuka kesempatan bagi murid untuk mengevaluasi dan memperbaiki pemahaman mereka saat mereka bertemu dengan pemikiran orang lain dan saat mereka berpartisipasi dalam pencarian pemahaman bersama. Dengan cara ini, pengalaman dalam konteks sosial memberikan mekanisme penting untuk perkembangan pemikiran murid. Konstruktivisme Vygotsky menekankan pada konstruksi pengetahuan yang dilakukan oleh murid melalui interaksi sosial 
dengan orang lain. Isi dari pengetahuan ini dipengaruhi oleh kultur di mana murid tinggal, yang mencakup bahasa, keyakinan, dan keahlian atau ketrampilan. Ada dua prinsip penting berkenaan dengan teori konstruktivisme sosial Vygotsky. Pertama, mengenai fungsi dan pentingnya bahasa dalam komunikasi sosial yang dimulai proses pencanderaan terhadap tanda sampai kepada tukar menukar informasi dan pengetahuan. Kedua, Zona of proximal development (ZPD). Pendidik sebagai mediator memiliki peran mendorong dan menjembatani siswa dalam upayanya membangun pengetahuan, pengertian dan kompetensi (John W. Santrock,2007).

Konstruktivisme merupakan landasan berpikir atau filosofi pembelajaran konstektual yang menyatakan bahwa pengetahuan dibangun oleh manusia secara secara bertahap, sedikit demi sedikit, yang hasilnya diperluas melalui konteks yang terbatas dan tidak sekonyong-konyong. Dalam proses belajar mengajar bahasa Inggris, konsep tersebut akan semakin padu dengan pembelajaran yang menyenangkan (joyful learning) sehingga diharapkan prestasi siswa akan semakin meningkat. Proses belajar yang dimaksudkan disini tidak hanya yang terjadi di dalam kelas (intensive class) akan tetapi juga di luar kelas (extensive class).

Tujuan dari karya pengabdian ini adalah pemberdayaan guru bahasa Inggris madrasah dengan Joyful Learnig-Based Social Constructivism Pedagogy dalam Kelas EFL. Kelas EFL merupakan kelas bahasa Inggris yang menjadi bahasa asing disuatu negera. Madrasah yang menjadi tujuan adalah tingkat Madrasah Tsanawiyah yang ada di kecamatan Boja Kabupaten Kendal. Pemberdayaan dilakukan secara sistematis diawali dengan Focus Group Discussion (FGD) hingga pendampingan kepada guru-guru madrasah untuk implementasi program.

\section{PENTINGNYA PENGGUNAAN BAHASA INGGRIS DI ERA GLOBALISASI}

Bahasa Inggris sebagai salah satu bahasa asing merupakan bahasa Internasional yang mempunyai peranan sangat penting untuk kelancaran interaksi antara berbagai Negara. Berangkat dari perkembangan ilmu dan teknologi serta tuntutan zaman yang semakin maju dan modern maka dibutuhkan sebuah penguasaan ketrampilan bahasa asing terutama bahasa Inggris sebagai alat komunikasi Internasional. Hal ini bertujuan agar kita sebagai warga Indonesia mampu bersaing dalam percaturan dunia dan mampu bersosialisasi dengan para pelaku pasar bebas di era globalisasi ini.

Di Indonesia banyak pendapat mengatakan bahwa belajar bahasa Inggris itu sangat penting bagi siapa saja baik untuk golongan tua maupun muda, 
mulai dari anak sekolah, orang biasa, para pekerja, pengusaha, mahasiswa, bahkan ibu rumah tangga. Hal ini disebabkan oleh faktor geografi, komunikasi, akses pada informasi. Ada tiga alasan yang masuk akal akan pentingnya bahasa Inggris bagi pengguna. Pertama, negara-negara yang ada disekitar Indonesia kebanyakan penduduknya menggunakan bahasa Inggris sebagai bahasa pertama atau kedua, seperti Singapura, Malaysia, Filipina, Australia, Selandia Baru, dan Papua Nugini. Faktor geografis menjadi alasan pertama mengapa orang Indonesia perlu mempelajari bahasa Inggris. Kedua, Bahasa Inggris perlu dipelajari karena penggunaanya secara luas sebagai bahasa komunikasi Internasional. Contoh yang mudah dilihat ada di dunia pariwisata. Para wisatawan yang melakukan perjalanan di negara asing biasanya menggunakan bahasa Inggris untuk dapat berkomunikasi dengan warga negara asli yang dikunjunginya. Dan ketiga, Bahasa Inggris digunakan untuk menyampaikan informasi yang terdapat di dunia. Bisa kita ambil contoh dari internet, sebagian besar situs-situs penyedia informasi di internet berbahasa Inggris. Tidak hanya di internet, buku-buku juga tidak sedikit yang memakai bahasa Inggris.

\section{BAHASA INGGRIS SEBAGAI BAHASA ASING (EFL)}

Bahasa Inggris merupakan bahasa asing yang sangat penting untuk dipelajari dan dikuasai khususnya oleh generasi muda khususnya para siswa(http://els.pppkpetra.or.id/index.php) karena bahasa Inggris merupakan bahasa Internasional yang paling sering digunakan. Artinya, Bahasa Inggris diakui dan dipakai oleh berbagai orang di seluruh penjuru dunia untuk berkomunikasi.

Bahasa Inggris adalah bahasa yang paling banyak digunakan di dunia untuk itulah diperlukan parenting bagi pembelajaran bahasa Inggris untuk anak (http://dyrahadi.blogspot.co.id/2015/14). Bahasa Inggris mempunyai peranan yang sangat penting dalam memasuki era globalisasi yang fungsinya tidak hanya sebagai alat atau media untuk berkomunikasi antarbangsa tetapi semakin luas dan penting, yaitu sebagai bahasa diberbagai disiplin ilmu pengetahuan, teknologi, sosial-ekonomi, budaya, bahkan seni oleh karena itu, pembelajaran bahasa Inggris sejak dini sangat dianjurkan.

Pendidikan bahasa Inggris akan sangat ideal jika dimulai sejak usia dini, terutama sebelum mereka menginjak umur 12 tahun. Hal ini disebabkan seorang anak memiliki periode emas untuk perkembangan bahasa anak. Mereka mampu belajar bahasa apapun seperti penutur aslinya dan sehingga periode ini harus dimanfaatkan sebaik-baiknya. Namun karena di Indonesia bahasa Inggris bukan merupakan bahasa ibu, tapi sebagai bahasa asing yang pertama. 
Kebutuhan masyarakat terhadap kemampuan berbahasa Inggris begitu pesat merupakan alas an pentingnya belajar bahasa Inggris. http://inspirasikumisku.blogspot.co.id/2015/05) Hal ini tampak jelas dari sekian banyak informasi yang menggunakan bahasa Inggris sebagai media komunikasi dalam bentuk lisan maupun tulisan. Penggunaan bahasa Inggris ini, telah menjalar hampir keseluruh pelosok dunia. Popularitas bahasa Inggris sesungguhnya bukan semata-mata usaha negara kategori pertama (inner circle countries) untuk menyebarkan bahasa mereka namun lebih kepada kesadaran masayarakat dunia akan pentingnya penguasaan bahasa Inggris.

Oleh karena itu Indonesia sebagai negera berkembang, penerapan terhadap pengguanaan bahasa inggris masih terlalu minim, keberadaannya hanya terdapat di tempat-tempat tertentu saja,terutama dikota-kota besar,yang pengguanaannya untuk kepentingan bersifat formal. Sebaliknya di daerah yang jauh dari perkotaan masih sangat sulit di temukan adanya penggunaan bahasa Inggris untuk berinteraksi dan berkomunikasi antar sesama masyarakat.

Dengan memperkenalkan bahasa Inggris sedini mungkin yang begitu trend sekarang ini akan memberikan ruang gerak bagi generasi muda bangsa untuk memahami betapa pentingnya belajar bahasa Inggris. Penguasaan bahasa Inggris tidak semestinya hanya bisa didapatkan dari sekolah saja melainkan banyak lembaga-lembaga yang turut andil dalam upaya pembelajaran bahasa Inggris.

Pembelajaran bahasa Inggris bukanlah sesuatu yang bisa dipandang sebelah mata, atau bisa diacuhkan begitu saja, karena penggunaanya tertumpu di setiap ranah kehidupan yang menjadi salah satu kunci untuk mencapai sukses dalam kehidupan yang serba modern ini. Hal tersebut menjadi kesesuaian untuk berinteraksi dengan masyarakat dunia lainnya, sehingga muncul hubungan yang saling menguntungkan dan tentunya dapat memperkaya ide-ide serta gagasan luas mengenai pola perkembangan dalam kehidupan dibanyak hal.

Pembelajaran bahasa inggris juga semata-mata karena semakin pesatnya persaingan global yang mengantarkan kita agar selalu berlomba-lomba menjadi lebih baik dari waktu ke waktu. Maka penguasaan hanya satu bahasa saja (bahasa ibu) sangatlah sulit untuk mencapai tujuan di ajang persaingan global yang modern ini.

Oleh karena itu pula, perubahan dan perbaikan terhadap pembelajaran bahasa inggris masih akan terus diperbaiki sehingga diharapkan pembelar dapat lebih mudah memahami dan memaknai pentingnya penguasaan bahasa inggris secara keseluruhan, serta berlandaskan pada aturan-aturan yang telah ditetapkan dan disetujui bersama. 
Di era globalisasi seperti saat sekarang ini alasan belajar bahasa Inggris semakin meluas dengan dimulainya perdagangan bebas aehingga bahasa Inggris paling banyak digunakan di dunia (http://www.ef.co.id/englishfirst/englishstudy). Pentingnya mempelajari dan menguasai bahasa Inggris, antara lain: Bahasa Inggris adalah bahasa yang paling sering digunakan oleh penutur bahasa asing di seluruh dunia; Menguasai bahasa Inggris dapat meningkatkan value Anda dan akan lebih di hargai pada dunia kerja internasional.

\section{JOYFUL LEARNING}

Joyful learning atau yang dikenal dengan pembelajaran menyenangkan merupakan pembelajaran yang melibatkan berbagai aspek dan rasa. Perasaan senang, bahagia, hingga nyaman baik dari guru dan siswa yang berada dalam proses belajar mengajar menjadi ciri pembelajaran ini. Mulyasa mendefinisikan pembelajaran menyenangkan atau Joyful Learning sebagi suatu proses pembelajaran yang didalamnya terdapat sebuah kohesi yang kuat antara pendidik dan peserta didik, tanpa ada perasaan terpaksa atau tertekan (Mulyasa, E.: 2006) Joyful learning memadukan berbagai strategi, konsep dan praktik pembelajaran. Perpaduan tersebut terdiri dari sinergi pembelajaran yang bermakna, pembelajaran kontekstual, teori konstruktivisme, pembelajaran aktif hingga psikologi perkembangan peserta didik.

Dalam pembelajaran bahasa Inggris, joyful learning juga dipadukan berbagai strategi untuk menciptakan lingkungan belajar yang efektif, menerapkan kurikulum, menyampaikan materi, yang memudahkan proses belajar dan mengakibatkan prestasi belajar siswa mengalami perbaikan atau peningkatan (Hasan, A., Othman, Z. \& Majzub, R. : 2015). Namun demikian, meskipun esensinya sama, bahkan metodologi pembelajaran yang dipilih juga sama, akan tetap ada perbedaan spesifikasi terkait dengan penekanan konseptualnya yang relevan baik itu berkaitan dengan perkembangan moral dan kejiwaan anak. Membangun dan menciptakan kebahagiaan peserta didik yang menjadikan mereka bersemangat dan gembira dalam belajar menjadi salah satu ciri pembelajaran ini karena mereka tahu apa makna dan gunanya belajar.

Pembelajaran dengan menggunakan pendekatan Joyful Learning harus memperhatikan beberapa faktor seperti kebermaknaan, penguatan, dan umpan balik. Kebermaknaan berarti peningkatan pemahaman terhadap informasi baru yang sesuai dengan gagasan dan pengetahuan yang telah dikuasai oleh peserta didik. Jika istilah dan konsep sulit dipahami, maka pemahaman tersebut perlu digali melalui pengalaman siswa tersebut. Penguatan merupakan pengulangan 
oleh guru dan latihan yang dilakukan oleh siswa. Dalam pendekatan Joyful Learning ini, penguatan merupakan sesuatu yang harus diperhatikan dengan seksama oleh guru. Umpan balik kegiatan belajar akan efektif jika siswa menerima materi yang diajarkan dengan cepat. Umpan balik sederhana dapat berupa koreksi jawaban siswa atas pertanyaan guru selama pelajaran berlangsung atau koreksi tugas yang dikerjakan oleh siswa (Darmansyah:2011).

\section{SOSIAL KONSTRUKTIVISME}

Konstruktivisme adalah suatu pandangan tentang proses pembelajaran yang menyatakan bahwa dalam proses belajar atau perolehan pengetahuan diawali dengan terjadinya konflik kognitif yang hanya dapat diatasi melalui pengetahuan diri, dan pada akhir proses belajar pengetahuan akan dibangun oleh peserta didik melalui pengalamannya dari hasil interkasi dengan lingkungannya (Karli, H. dan Yuliariatiningsih, M.S.: 2003). Konstruktivisme beranggapan bahwa pengetahuan adalah hasil konstruksi manusia melalui interaksi dengan objek, fenomena pengalaman dan lingkungan mereka.

Secara garis besar prinsip-prinsip konstruktivisme yang diambil dalam pembelajaran adalah pengetahuan dibangun oleh siswa sendiri, baik secara personal maupun secara sosial; pengetahuan tidak dipindahkan dari guru ke siswa, kecuali dengan keaktifan siswa sendiri untuk bernalar; siswa aktif mengkonstruksi secara terus menerus, sehingga terjadi perubahan konsep menuju ke konsep yang lebih rinci, lengkap, serta sesuai dengan konsep ilmiah; guru berperan membantu menyediakan sarana dan situasi agar proses konstruksi siswa berjalan mulus (Suparno, P.: 2001). Dengan pendekatan ini, untuk mendorong agar siswa terlibat aktif dalam kegiatan belajar, maka suasana lingkungan belajar harus demokratis; kegiatan pembelajaran berlangsung secara interaktif dan berpusat pada siswa; pendidik mendorong siswa agar belajar mandiri dan bertanggungjawab atas kegiatan belajarnya (Nurhidayati, Euis ; 2017).

Pedagogi konstruktivisme sosial (Social Constructivism Pedagogy), menurut Adams (2006) lebih menekankan pada konsepsi yang mendasari konstruktivisme sosial, keyakinan ajaran yang mengatur, merancang lingkungan belajar, dan tantangan dari pendekatan dalam praktek.

\section{DESAIN PROGRAM}

Artikel ini berusaha memberikan gambaran tentang kegiatan mengemas pembelajaran bahasa Inggris sebagai bahasa asing (EFL) di dua madrasah yang sudah dipilih di kecamatan Boja Kabupaten Kendal. Dalam memperkenalkan 
dan mengimplemetasikan konsep joyful based social constructivism pedagogy ini, di kembangkan dari tiga konsep pemberdayaan yaitu sosalisasi, pelatihan, dan pendampingan (Prayogo, A. \& Widyaningrum, L.; 2017)., menjadi empat tahap yang meliputi sosialisasi dan pelatihan; pemberian modelling dikelas-kelas; pelibatan guru dalam praktik di kelas-kelas; dan pendampingan guru untuk praktik secara mandiri di kelas-kelas.

Sosialisasi dan pelatihan diawali dengan observasi yang bertujuan untuk mengetahui kondisi riil siswa dan guru di madrasah yang akan menjadi dampingan. Sosialisasi dan pelatihan bertujuan untuk memberikan gambaran program dan konsep pembelajaran yang akan ditingkatkan. Setelah itu, modelling diberikan oleh insruktur kepada guru langsung di kelas. Setelah itu, guru bersama dengan instruktur ikut terlibat dalam pembelajaran di kelas. Pada tahap akhir, guru mengajar di kelas sendiri tanpa dibantu oleh instruktur untuk mepraktikkan konsep yang telah diajarkan. Pada tahap ini, guru akan didampingi oleh instruktur dan pengabdi pada saat mengajar di kelas.

\section{KEMASAN PROGRAM DENGAN JOYFUL LEARNING BASED SOCIAL CONSTRUCTIVISM PEDAGOGY}

Dalam mengemas pembelajaran Joyful Learning based Social Constructivism Pedagogy, langkah pertama yang dilakukan adalah melakukan observasi madrasah yang akan dijadikan tempat praktik. Langkah ini bertujuan untuk mengetahui sejauh mana pembelajaran bahasa Inggris oleh guru-guru bahasa Inggris di kelas dan minat belajar siswa dalam bahasa Inggris. sekaligus menentukan sekolahan yang akan diberi pelatihan dan pendampingan. Hasil observasi menunjukkan bahwa minat belajar bahasa Inggris bagi para siswa sebetulnya cukup baik, hal ini karena bahasa Inggris merupakan salah satu mata pelajaran yang diujikan pada Ujian Nasional. Akan tetapi, guru bahasa Inggris cenderung lebih menekankan pada penyelesaian materi untuk menghadapi Ujian sehingga kurang menghiraukan keadaan kelas apakah pembelajarannya memuaskan dan menyenangkan atau tidak bagi siswa. Akhirnya, ditentukanlah 2 madrasah tsanawiyah yaitu MTS NU 02 AL Ma'arif Boja dan MTS NU 14 Kaligading Boja dengan mempertimbangkan bahwa kedua madrasah tersebut bisa mewakili sekolahan yang memndapatkan animo murid banyak dan sekolahan yang mendapatkan animo murid yang tidak terlalu banyak. Selain itu, diketahui pula bahwa data bahwa pembelajaran bahasa Inggris di wilayah tersebut masih sangat memerlukan pelatihan skill tertentu.

Sosialisasi dilaksankan di dua madrasah tersebut untuk memberikan gambaran program yang akan dilaksanakan. Sosialisai dilaksanakan di Mts NU 
02 Al Ma'arif Boja pada tanggal 17 Juli 2017, dan di Mts NU 14 Kaligading Limbangan pada 18 Juli 2017. Dalam kegiatan sosialisasi tersebut, disepakati beberapa hal seperti penentuan jadwal pelatihan yag dikemas dalam Focus Group Discussion (FGD) dan Pelaksanaan Penerapan Joyful Learning di Kelas EFL. Kegiatan FGD diikuti oleh Guru kelas Bahasa Inggris dari masing-masing madrasah yang berjumlah 4 orang. Kegiatan FGD dilaksanakan pada tanggal 3 Agustus 2017 di kampus UIN Walisongo ruang microteaching. FGD ini di pandu oleh dua orang pemateri utama yaitu Siti Tarwiyah, S.S., M.Hum. yang menyampaikan strategi-strategi pembelajaran menyenangkan joyful learningbased social construcivism pedagogy dan Currriculum 2013 (revised) dan Agus Prayogo, M.Pd. yang menampaikan dan memberikan contoh-contoh penerapan Joyful learning di kelas EFL. Selain itu, kegiatan ini diawali dengan sesi sharing tentang permasalahan yang dihadapi sekolah dalam pembelajaran Bahasa Inggris.

Beberapa hal yang di hasilkan dalam FGD adalah seperti permasalahan guru yang merasa sudah maksimal dalam mengajar dengan berbagai metode, akan tetapi belum berhasil meningkatkan motivasi belajar siswa. Mereka sudah berusaha sekeras mungkin untuk menarik perhatian para siswa dengan menggunakan berbagai macam tehnik dan strategi pengajaran namum hasilnya tetap tidak memuaskan dan merasa semakin putus asa untuk menggunakannya. Beberapa kemungkinan penyebabab hal ini adalah disebabkan oleh rendahnya input SDM siswa karena sebagian besar yang masuk ke madrasah tersebut adalah yang tidak diterima masuk sekolah negeri disekitar mereka. Akibatnya, guru-guru tersebut cenderung asal mengajar, dan menyelesaikan materi dan fokus menyiapkan untuk Ujian Nasional. Dengan refreshment dan pemaparan materi dari narasumber, dan diikuti dengan praktek penerapannya, mereka termotivasi untuk mencoba mempraktekannya di kelas. Dari pemaparan narasumber didapatkan bahwa sebagai guru seharusnya tidak hanya diperlukan mencari berbagai tehnik yang menyenangkan dalam pembelajaran bahasa Inggris, akan tetapi juga harus memperhatikan kondisi siswa, dan apa yang disukai oleh siswanya, sehingga mereka akan belajar dengan tidak terpaksa karena suasana yang sesuai dengan yang mereka inginkan.

\section{IMPLEMNTASI JOYFUL LEARNING BASED SOCIAL CONSTRUCTIVISM PEDAGOGY}

Praktek penerapan joyful learning based social constructivism di kelas EFL di dua madrasah yang sudah dipilih dilakukan sesuai dengan tiga tahap 
desain. Hal ini karena satu tahap dari empat total desain yaitu sosialisasi dan pelatihan selesai dilaksanakan. Adapun implementasinya adalah sebagai berikut:

Pelaksanaan pengabdian di MTs NU 02 Al Ma'arif Boja meliputi tahapan berikut. Tahap pertama dari desain program ini adalah pemberian contoh atau modeling kepada guru pengampu mata pelajaran bahasa Inggris. Tahap ini dilakukan setelah sosialisasi dan pelatihan dimana guru berperan sebagai pengamat. Praktik pertama penerapan joyful learning based social constructivism pedagogy ini dilakukan di MTS NU 02 Al MA'arif Boja oleh tim Pengabdi, yaitu Dra. Nuna Mustikawati Dewi. Dalam praktik ini, pengabdi dibantu oleh dua orang dosen bahasa Inggris yaitu Lulut Widyaningrum, M.Pd., dan Agus Prayogo, M.Pd., yang berperan sebagai instruktur sekaligus sebagai narasumber pada saat refleksi pasca praktik mengajar. Untuk memaksimalkan Tim Pengabdi dibantu oleh dua orang mahasiswa, Ainul Bahar dan Khoirul Umam yamg memberikan modeling dan terjun langsung di kelas. Kegiatan ini dilaksanakan pada hari Sabtu tgl 5 Agustus 2017. Setelah kegiatan berakhir, dilanjutkan dengan refleksi antara Tim pengabdi, mahasiswa dan guru. Instruktur sudah mencoba menerapkan joyful learning dengan mengikuti kemauan siswa baru diarahkan ke materi dengan diselingi games. Kebetulan siswa yang diajar untuk praktik adalah siswa kelas IXB yang merupakan kelas spesial dengan siswa yang over aktif dan terbilang nakal. Walaupun pada awalnya cukup sulit dalam berkomunikasi, namun sedikit demi sedikit siswa mulai antusias mengikuti pembelajaran yang menggunakan game dan mengikuti alur keinginan siswa yang sangat aktif. Keadaan ini cukup membuat guru kelas terkejut karena selama ini sangat direpotkan dengan kelas tersebut.

Tahap kedua adalah praktik antara narasumber dan guru pengampu mata pelajaran di kelas. Praktek kedua penerapan joyful learning based social constructivism pedagogy ini dilakukan berkolaborasi antara tim Pengabdi, sebagai instruktur dan guru bahasa Inggris yaitu Ibu Diyah Fitri N., S.S yang terjun langsung di kelas. Materi tetap disampaikan oleh instruktuk dan guru kelas, dan dari tim juga membangun suasana belajar yang menyenangkan pada saat brainstorming dan ice breaking sesuai dengan materi yang diajarkan. Praktek penerapan joyful learning di kelas ini dilaksankan pada hari Sabtu tgl 19 Agustus 2017. Setelah kegiatan berakhir, dilanjutkan dengan refleksi antara Tim pengabdi, mahasiswa yang mendampingi dan guru. Pelaksanaan peer-teaching dalam praktek yang kedua ini dimaksudkan agar guru mulai bisa membiasakan diri untuk membangun suasana kelas yang menyenangkan sehingga siswa mulai berani berkomunikasi dengan bahasa Inggris yang sederhana. Pada tahap ini, siswa sudah mulai terlihat lebih antusias mengikuti pelajaran dengan lebih berani 
menjawab pertanyaan dan bahkan berani bertanya dengan menggunakan bahasa Inggris yang sangat sederhana.

Tahap ketiga adalah tahap dimana guru melakukan praktik mengajar dikelas dengan mengimplementasikan joyful learning based social constructivism pedagogy ini. Praktek ketiga penerapan joyful learning based social constructivism pedagogy ini dilakukan di MTS NU 02 Al MA'arif Boja dilakukan oleh guru bahasa Inggris di sekolajan tersebut yang terjun langsung di kelas. Materi tetap disampaikan oleh guru kelas. Praktek penerapan joyful learning di kelas ini dilaksanakan pada tanggal 21 Agustus 2017. Guru yang mengajar adalah Ibu Anjaryani, S.Pd., Bpk. Erwin Agung P, S.S. dan Ibu Diyah Fitri N., S.S memantau proses pembelajarannya dibantu oleh tim pengabdi yang sekaligus melaksanakan pendampingan.

Setelah kegiatan berakhir, dilanjutkan dengan refleksi antara Tim pengabdi dan guru-guru. Suasana kelas yang kondusif dan siswa sudah mulai menikmati pross belajar dan berani berkomunikasi dengan baik. Siswa terlihat antusias mengikuti pelajaran dengan lebih berani menjawab pertanyaan dan bahkan berani bertanya dengan menggunakan bahasa Inggris. Poin kredit lainnya adalah guru sudah mulai lebih variatif dalam mengelola kelas, pada saat brainstorming, penyampaian materi dengan teknik yang berbeda-beda dan menggunakan media yang ada di sekitarnya.

Berakhirnya tahap ketiga bukan berarti program ini telah selesai. Pendampingan terhadap guru mata pelajaran bahasa Inggris tetap dilakukan untuk beberapa waktu untuk memastikan guru dapat benar-benar mengimplementasikan dan mengatasi berbagai permasalahan yang ditemui. Pendampingan pertama dilaksanakan di MTs NU 2 Al Maarif Boja pada tanggal 23 Agustus 2017. Pada pendampingan ini, ibu Dyah Fitri, S.S. selaku guru pengampu menyampaikan materi di kelas IX, speaking ability tentang self Introduction and Introduction to others. Materi ini sebagai antisipasi ujian praktik pada saat ujian sekolah. Brainstorming diawali dengan melihat video kartun yang menggambarkan self introduction. Dengan antusias siswapun bisa bereksplorasi mengisi kolom-kolom yang masih kosong. Dalam penerapan materinyapun sudah mencoba icebreaking dengan menampilkan gambar orang yang sedang saling berkenalan. Kelaspun diakhiri dengan performance siswa untuk mempraktekkan self introduction dan introduction to others. Pendampingan kedua dilaksanakan dilaksanakan pada tanggal 24 Agustus 2017 dengan guru yang berbeda. Bapak Erwin menyampaikan materi kelas VII dengan materi tentang telling about myself. Dalam brainstorming siswa diajak untuk mengeksplore melalui sebuah lagu tentang myself. Akhrinya siswa menirukan 
talking self tersebut dan mulai mengenal istilah yang dipakai dan juga bisa membaca dan memahami ID card dalam bahasa Inggris. Pendampingan yang ketiga dilaksanakan pada tanggal 26 Agustus 2017 dengan guru kelas yang mengajar Ibu Anjar Yani, S.Pd. Pada saat itu guru mengajarkan tentang tentang giving instruction and response, probibition and giving permission. Kelas diawali dengan brainstorming oleh guru dengan memberikan beberapa instruksi sederhana dalam bahasa Inggris tentang hal-hal yang biasa dilakukan sebelum pelajaran dimulai seperti, clean the board, close the door, don't be noisy dsb. Siswapun mulai terbiasa dengan response English instruction. Pada saat ice breaking guru memberikan gambar-gambar hal yang tidak boleh dilakukan seperti no littering, no smoking $d s b$. Kelaspun semakin bersemangat pada saat melakukan permainan secara berkelompok untuk memberikan dan melakukan perintah yang diberikan oleh kelompok lain

Kegiatan pendampingan ini diakhiri dengan refleksi dan evaluasi penerapan Joyful Learning di kelas EFL setelah praktek mulai dari tim pengabdi dan kolaborasi antara guru dan tim pengabdi, dan penerapan oleh guru sendiri. Para guru pun ditugaskan untuk melakukan Rencana Tindak Lanjut (RTL) untuk kegiatan selanjutnya.

Tidak jauh beda, pelaksanaan pengabdian di MTs NU 14 Al Ma'arif Kaligading Boja juga dengan beberapa tahap. Tahap pertama dilakukan seperti di madrasah sebelumnya yaitu melakukan modeling. Praktek pertama penerapan joyful learning based social constructivism pedagogy di MTs NU 14 Al Ma'arif Kaligading ini dilakukan juga oleh tim Pengabdi, yaitu Dra. Nuna Mustikawati Dewi, yang dibantu oleh dua dosen bahasa Inggris yang terlibat sebelumnya yang berperan baik itu sebagai instruktur sekaligus sebagai narasumber pada saat refleksi setelah prakatek mengajar. Tim Pengabdi tetap dibantu oleh 2 orang mahasiswa, Ainul Bahar dan Khoirul Umam yang berperan sebagai pemberi modeling yang terjun langsung di kelas. Pelaksanakan praktek penerapan joyful learning di kelas ini pada hari Sabtu tgl 12 Agustus 2017. Setelah kegiatan berakhir, dilanjutkan dengan refleksi antara Tim pengabdi, mahasiswa pemberi model dan guru. Dalam kegiatan ini terlihat siswa sangat senang dengan kedatangan tim pengabdi dan mahasiswa yang berperan sebagai instruktur. Siswa di MTs ini cenderung lebih teratur dari sebelumnya dikarenakan dan cukup antusias menerima pembelajarannya. Guru kelasnya pun sangat termotivasi dengan melihat anak didiknya mulai memperhatikan dengan seksama pembelajaran yang diberikan dengan diselingi game-game kecil dan yel-yel dalam bahasa Inggris. 
Pada tahap kedua, praktik dilakukan oleh secara bersama antara instruktur yang memberi model dengan guru mata pelajaran bahasa Inggris. Praktek kedua dari penerapan joyful learning based social constructivism pedagogy ini dilakukan juga dengan berkolaborasi antara tim Pengabdi, sebagai instruktur dan guru bahasa Inggris yaitu Bapak Ari Yanuarrahman, S.Pd. yang terjun langsung di kelas. Materi tetap disampaikan oleh guru kelas diawal dan instruktur mendampingi proses belajar mengajar, sedangkan dari tim hanya membangun suasana belajar yang menyenangkan pada saat brainstorming dan ice breaking sesuai dengan materi yang diajarkan. Pelaksanakan praktek penerapan joyful learning di kelas pada tahap ini dilaksanakan pada hari tgl 26 Agustus 2017. Setelah kegiatan berakhir, dilanjutkan dengan refleksi antara Tim pengabdi, mahasiswa dan guru. Pelaksanaan peer teaching dalam praktek yang kedua ini dimaksudkan agar guru mulai bisa membiasakan diri untuk membangun suasana kelas yang menyenangkan sehingga siswa mulai berani terlibat dalam pembelajaran atau bahkan mampu berkomunikasi dengan bahasa Inggris yang dasar sekalipun. Dari tahap ini sudah mulai terlihat siswa lebih antusias mengikuti pelajaran dengan lebih berani menjawab pertanyaan namum belum mulai berani bertanya.

Pada tahap ketiga, praktik penerapan joyful learning based social constructivism pedagogy ini dilakukan di MTS NU 14 Al MA'arif Kaligading dilakukan oleh guru bahasa Inggris di sekolahan tersebut yang terjun langsung di kelas. Materi tetap disampaikan oleh guru kelas. Pelaksanakan praktek penerapan joyful learning di kelas ini pada tanggal 28 Agustus 2017. Guru yang mengajar adalah bapak Ari Yanuarrahman, S.Pd. Tim pengabdi memantau kegiatan tersebut yang sekaligus melaksanakan pendampingan. Setelah kegiatan berakhir, dilanjutkan dengan refleksi antara Tim pengabdi dan guru-guru. Suasana kelas yang menyenangkan bagi siswa sudah mulai terbangun sehingga siswa mulai berani melakukan interaksi dan kolaborasi dengan siswa yang lain atau berkomunikasi dengan bahasa Inggris sederhana. Siswa juga terlihat mulai lebih antusias mengikuti pelajaran dengan lebih berani menjawab pertanyaan dan bahkan berani bertanya dengan menggunakan bahasa Inggris. Guru pun sudah mulai variatif dalam mengelola kelas, pada saat brainstorming, penyampaian materi dengan teknik yang berbeda-beda dan menggunakan media sederhana yang berasal dari benda atau barang yang ada di sekitarnya.

Seperti halnya di madrasah sebelumnya, berkahirnya tahap ketiga juga diikuti dengan pendampingan yang dilakukan pada tanggal 29 Agustus 2017 di madrasah yang sama, yaitu MTs NU 14 Kaligading. Pendampingan dilakukan untuk menampingi bapak Ari Yanuarrahman, S.Pd. yang menyampaikan materi 
tentang procedural text. Dengan ditanyakan tentang hobi masing-masing siswa, guru mengambil contoh salah satu hobi siswa dan mulai membuat text bersama tentang langkah-langkah secara berurutan dalam melakukan hobi tersebut yang kebetulan cerita tentang berenang atau swimming. Dalam ice breaking guru mulai memasukkan media gambar yang menggambarkan proses pembuatan kertas yang selama ini jauh dari bayangan para siswa.

\section{KENDALA DAN HAMBATAN}

Secara garis besar, pada umumnya para guru bahasa Inggris baik itu di M.Ts NU 02 Al Ma'arif Boja dan MTs 14 Al Ma'arif Kaligading sudah mulai membiasakan menggunakan berbagai macam metode dan teknik yang bervariasi khususnya dalam brainstorming dan ice breaking di tengah-tengah penyampian materi. Hanya saja pada saat diberi istilah baru sebagai inovasi agar tidak monoton mereka lambat dalam meresponnya. Oleh karena itu butuh pengulangan berkali-kali agar mereka terbiasa.

Social constructivism pedagogy yang dilakukan oleh guru di kelas belum bisa secara maksimal memotivasi siswa untuk ikut terlibat dalam berkomunikasi dalam bahasa Inggris. Hal ini kemungkinan dikarenakan kosakata mereka masih terbatas sehingga pelaksanaan belum maksimal. Pembiasaan penerapan joyful learning harus selalu lebih variatif agar para siswa tidak merasa bosan. Hal ini merupakan tantangan bagi guru untuk selalu mencari tehnik dan media yang tidak sama dari satu waktu ke waktu yang lain. Jumlah jam yang tersedia tidak memberikan kesempatan lebih sehingga menjadikan guru kurang maksimal dalam menggunakan dan mengimplementasikan joyful learning. Hal ini dikarenakan guru-guru harus menyelesaikan materi dan pemahaman siswa. Di sisi lain, menyelesaikan materi adalah hal yang sangat penting mengingat bahasa Inggris merupakan mata pelajaran yang diujikan dalan Ujian Nasional. Jumlah materi yang harus diselesaikan tidak seimbang dengan waktu yang ada khususnya yang ingin berfokus pada penggunaan joyful learning dalam brainstorming dan ice breaking.

\section{KESIMPULAN}

Kegiatan implementasi hasil pelatihan joyful learning based social constructivism pedagogy dilaksanakan di dua madrasah tsanawiyah dampingan. Hampir semua sekolah sudah mampu mengimplementasikan strategi pembelajaran yang menyenangkan di kelas EFL, yang diperkenalkan dengan baik itu dalam bentuk permainan atau games di saat brainstorming ataupun ice breaking. Pendampingan dilaksanakan untuk mengawal pelaksanaan dan juga 
untuk memberikan penguatan kepada seluruh guru untuk melanjutkan program joyful learning ini. Pelatihan dan pendampingan program yang telah dilaksanakan dalam program pengabdian ini masih sebatas pada aplikasi teknik yang diperkenalkan dalam pelatihan. Harapannya, guru-guru menjaga komitmen mereka untuk memperhatikan dan membimbing siswa secara konsisten dan telaten. Improvisasi terhadap teknik dan media ajar sangat dianjurkan untuk menjembatani rasa bosan dalam proses pembelajaran di kelas. 


\section{DAFTAR PUSTAKA}

Adams, P. (2006). Exploring social constructivism: Theories and practicalities, education 3-13. International Journal of Primary, Elementary and Early Years of Education, 34(3), 243-257.

Brandt, Ronald. (1993). What do you mean professional. Educational Leader-ship. Nomor 6, 50, March.

Carolin Rekar Munro. (2005). "Best practices" in teaching and learning : Challenging current paradigms and redefining their role in education. The College Quarterly. 8 (3), $1-7$.

Darmansyah. (2011). Strategi Pembelajaran Menyenangkan Dengan Humor. Jakarta: Bumi Aksara.

Hasan, A., Othman, Z. \& Majzub, R. (2015) Using Active, Creative, Effective and Joyful (ACEJ) Learning Strategies toward English Achievement and their Behavioural Changes among Primary School Students. Mediterranean Journal of Social Sciences. 6 (6): 455-459.

John W. Santrock. (2007), Psikologi Pendidikan, Edisi Kedua, Jakarta: Kencana, hlm. 390.

Karli, H. dan Yuliariatiningsih, M.S. (2003). Model-Model Pembelajaran. Bandung : Bina Media Informasi.

Mulyasa, E.(2006). "Menjadi guru profesional : menciptakan pembelajaran kreatif dan menyenangkan”. Bandung: Remaja Rosdakarya. H.191-194.

Nurhidayati, Euis. (2017). Pedagogi Konstruktivisme Dalam Praksis Pendidikan Indonesia. Indonesian Journal of Educational Counseling. 1 (1). 1-14.

Prayogo, A. \& Widyaningrum, L. (2017). Implementasi Metode Fonik dalam Pengenalan Bunyi Bahasa Inggris. Dimas: Jurnal Pemikiran Agama untuk. Pemberdayaan. 17 (1): 97-110. DOI: $\underline{\text { 10.21580/dms.2017.171.1506 }}$

Suparno, P. (2001). Filsafat Konstruktivisme dalam Pendidikan. Yogyakarta : Kanisius. 